\title{
Reveal the growth mechanism in perovskite films via weakly coordinating solvent annealing
}

\author{
Yafei Wang ${ }^{1}$, Detao Liu ${ }^{1}$, Peng Zhang ${ }^{1}$, Ting Zhang ${ }^{1}$, Waseem Ahmad ${ }^{1}$, Xiangxiao Ying ${ }^{1}$, \\ Feng Wang ${ }^{1}$, Jian $\mathrm{Li}^{1}$, Li Chen ${ }^{1}$, Jiang $\mathrm{Wu}^{3,4}$, Zhi David Chen ${ }^{1,2^{*}}$ and Shibin $\mathrm{Li}^{{ }^{*}}$
}

\begin{abstract}
In this study, we investigated the nucleation mechanism of perovskite films by employing isopropanol (IPA), a weakly coordinating solvent, to anneal both $\mathrm{PbI}_{2}$ and $\mathrm{CH}_{3} \mathrm{NH}_{3} \mathrm{PbI}_{3}$ in the sequential deposition and $\mathrm{CsPbI}_{3}$ in the one-step deposition. IPA solvent annealing (IPA SA) of $\mathrm{PbI}_{2}$ films was carried out at different temperatures. The grain size, compactness, roughness and morphology of $\mathrm{PbI}_{2}$ and $\mathrm{CH}_{3} \mathrm{NH}_{3} \mathrm{PbI}_{3}$ films were seriously affected by annealing methods. Similarly, weakly coordinating solvent annealing process was also employed to anneal all inorganic $\mathrm{CsPbI}_{3}$ perovskite in a one-step method. A continuous and dense $\mathrm{CsPbI}_{3}$ film with uniform grain size was obtained. We recognized that weakly coordinating solvent annealing for perovskite could regulate the dissolution-recrystallization process via controlling the volume of residual solvent in perovskite intermediate films. The power conversion efficiency (PCE) of conventional $\mathrm{CH}_{3} \mathrm{NH}_{3} \mathrm{PbI}_{3}$ perovskite solar cells (PSCs) reached $17.4 \%$ and that of $\mathrm{CsPbI}_{3}$ PSCs reached $2.5 \%$ based on this sequential IPA SA process.
\end{abstract}

Keywords: perovskite solar cells, solvent annealing, weak coordinating solvent, recrystallization

\section{INTRODUCTION}

Organic-inorganic hybrid perovskite solar cells (PSCs) have stimulated great interests in academia due to their ultrafast development of performance. The power conversion efficiency (PCE) of PSCs has reached 22.1\% from $3.8 \%$ in the past few years $[1,2]$. Increasingly more attention is paid to reveal the growth kinetics of perovskite in deposition process to further improve the performance of perovskite solar cells [3-20].

Sequential deposition method was firstly proposed by Grätzel's group in 2013 [18]. This method is an easy way to control the morphology of perovskite films because mesoporous $\mathrm{TiO}_{2}$ limits the crystal size of $\mathrm{PbI}_{2}$ which is the precursor in the fabrication of $\mathrm{CH}_{3} \mathrm{NH}_{3} \mathrm{PbI}_{3}$. A lot of publications study the properties (morphology, crystallinity, etc.) of $\mathrm{PbI}_{2}$ which plays an important role in the nucleation of perovskite films. It was obvious that a good crystalline $\mathrm{PbI}_{2}$ film with a rough surface could enlarge perovskite film grains. The better crystallization and greater specific surface area gradually become the desired characteristics of lead iodide precursor in two-step deposition method [21-27]. However, it is difficult to precisely control the growth time and growth rate of perovskite grains at mesoscopic domains. Also, for some other cases, such as application of perovskite for LED, controlled grain size is needed [28-32]. Meanwhile, some investigations focused on the direct treatment of perovskite films. Solvent annealing is an effective way to control the morphology and improve the surface performance of films. Huang et al. [33] firstly used DMF solvent annealing for perovskite films to reduce the grain boundaries in the year of 2014. Dai's group [34] investigated the intermediates of $\mathrm{MAI}-\mathrm{PbI}_{2}-\mathrm{DMF}$ and MAI$\mathrm{PbI}_{2}$-DMSO in a one-step method. In order to obtain better quality perovskite films, various solvents and methods were employed in the solvent annealing process [35-41]. These investigations improved grain growth, crystallization, and morphology of perovskite films. Unlike other solvent engineering processes, solvent anneal-

\footnotetext{
${ }^{1}$ State Key Laboratory of Electronic Thin Films and Integrated Devices, and School of Optoelectronic Information, University of Electronic Science and Technology of China, Chengdu 610054, China

${ }^{2}$ Department of Electrical \& Computer Engineering, and Center for Nanoscale Science \& Engineering, University of Kentucky, Lexington, Kentucky 40506, USA

${ }^{3}$ Institute of Fundamental and Frontier Sciences, University of Electronic Science and Technology of China, Chengdu 610054, China

${ }^{4}$ Department of Electronic and Electrical Engineering, University College London, Torrington Place, London WC1E7JE, United Kingdom

*Corresponding authors (emials: shibinli@uestc.edu.cn (Li S); zhichen@engr.uky.edu (Chen Z))
} 


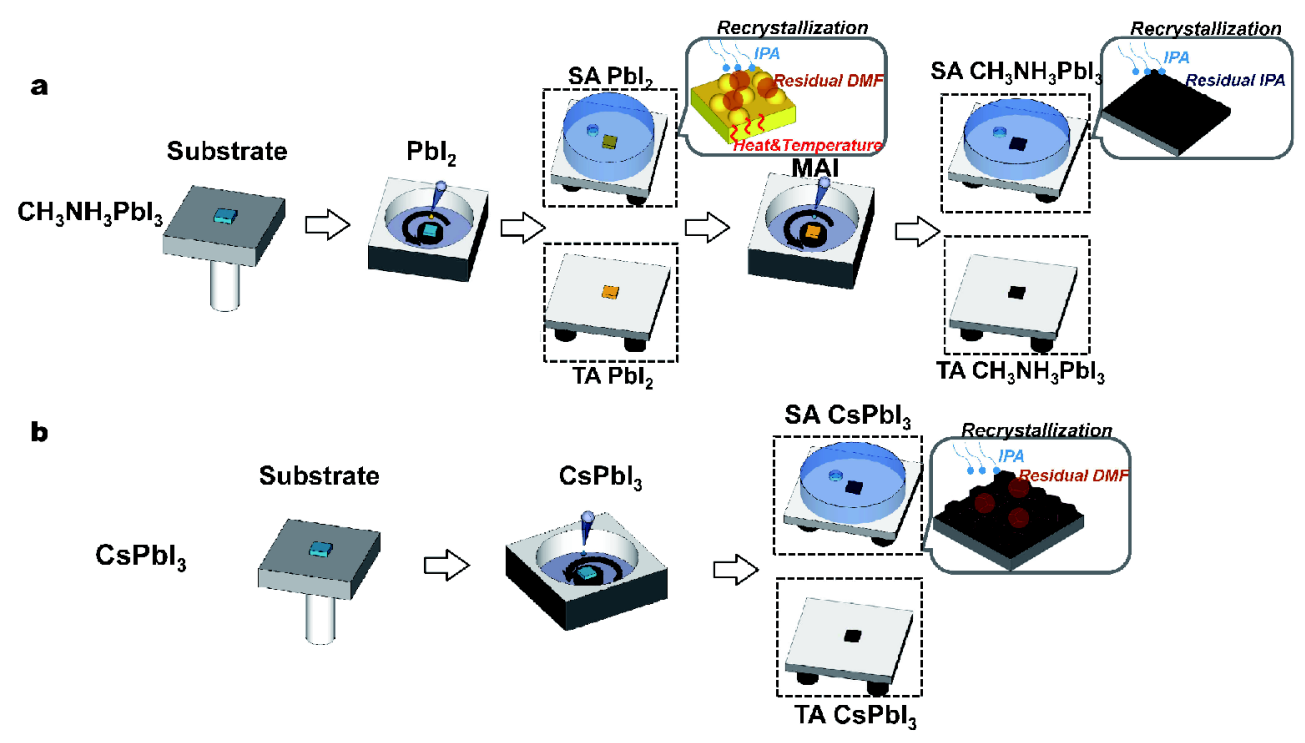

Figure 1 The schematic diagram of fabrication methods for PSCs. (a) Sequential deposition; (b) one-step deposition.

ing is more suitable for surface morphology modification and investigation of nucleation. The vapor generally reacts strongly with nuclei on the surface of the film and affects the evaporation of residual solvent in films. However, very few researchers analyzed the densification and growth mechanism of perovskite films. Compared with those most commonly used strongly coordinating solvent (such as DMF, dimethyl sulfoxide (DMSO) and $\gamma$ butyrolactone (GBL)), very few researchers deeply studied weakly coordinating solvents (ethanol, acetonitrile, isopropanol, etc.) in fabrication of perovskite films $[9,35,36,40]$. But these weakly coordinating solvents could successfully mediate the nucleation and grain growth of perovskite films. Weakly coordinating solvents are more effective in modifying the morphology and affecting the initial nucleation during film formation instead of expanding nuclei from the original strongly coordinating solvent. The investigation of the influence of weak coordinating solvent for the perovskite nuclei growth is very important and useful.

Here we employed a weakly coordinating solvent annealing method using isopropanol (IPA) solvent annealing to study the growth kinetics of perovskite films (Fig. 1). IPA solvent annealing (IPA SA) was applied to anneal $\mathrm{PbI}_{2}$ and $\mathrm{CH}_{3} \mathrm{NH}_{3} \mathrm{PbI}_{3}$ films in the sequential deposition method and also used for $\mathrm{CsPbI}_{3}$ films in the one-step deposition process. For $\mathrm{PbI}_{2}$, IPA SA improved crystallization and increased the roughness of the films. Furthermore, the IPA vapor could slow down the volatilization of methylammonium iodide (MAI) and increase the nucleation density of perovskite, which made the nucleation distribution more uniform in annealing of perovskite. The best $\mathrm{CH}_{3} \mathrm{NH}_{3} \mathrm{PbI}_{3}$ perovskite solar cell with a pinhole free film exhibited a PCE of $17.1 \%$ and PSCs with a $\mathrm{CsPbI}_{3}$ film showed a 30-fold improvement in PCE. Meanwhile, the stability and crystallinity of $\mathrm{CsPbI}_{3}$ films were improved due to the formation of smaller clusters and better film compactness $[28,29]$. To the best of our knowledge, this is the first time that solvent annealing is used in the deposition of inorganic perovskite films. The investigation of IPA SA could be very useful for understanding the growth kinetics of both organic-inorganic hybrid and inorganic perovskites during deposition.

\section{EXPERIMENTAL SECTION}

\section{Materials}

$\mathrm{PbI}_{2}, \mathrm{CH}_{3} \mathrm{NH}_{3} \mathrm{I}$, CsI, titanium diisopropoxide bis(acetylacetonate) and spiro-OMeTAD were purchased from Sigma-Aldrich. Titanium dioxide nanoparticles $(20 \mathrm{~nm}$ particle size) and solvents, 2-propanol (IPA, 99.5\%) and DMF, DMSO, and acetone, were provided by Dyesol and Kelon respectively.

\section{$\mathrm{MAPbI}_{3}$ solar cells fabrication}

Fluorine-doped tin oxide (FTO) glass substrates were cleaned sequentially in alkaline detergent, acetone, etha- 
nol, and DI water for 15 min each, followed by drying with $\mathrm{N}_{2}$ flow. A compact layer of $\mathrm{TiO}_{2}\left(\mathrm{c}-\mathrm{TiO}_{2}\right)$ was deposited via spray pyrolysis at $450^{\circ} \mathrm{C}$ from a precursor solution of titanium diisopropoxide bis (acetylacetonate) in ethanol (volume ratio 1:39). The films were annealed at $500^{\circ} \mathrm{C}$ for $20 \mathrm{~min}$ and then cooled down to room temperature. The mesoporous $\mathrm{TiO}_{2}\left(\mathrm{~m}-\mathrm{TiO}_{2}\right)$ scaffold was spin-coated at 5,000 rpm for $30 \mathrm{~s}$ and annealed at $500^{\circ} \mathrm{C}$ for $30 \mathrm{~min}$, in which the pristine paste was diluted in ethanol (weight ratio, 2:7). $\mathrm{CH}_{3} \mathrm{NH}_{3} \mathrm{PbI}_{3}$ was synthesized using the two-step spin coating method and the following experiments except for gold deposition were carried out in a glove box in nitrogen. $60 \mu \mathrm{L}$ of $\mathrm{PbI}_{2}$ solutions in DMF $\left(1 \mathrm{~mol} \mathrm{~L}^{-1}\right)$ were first spin-coated onto the substrates at 3,500 and 5,000 rpm for 3 and $5 \mathrm{~s}$ respectively. The films were annealed in nitrogen (called thermal annealing) or in IPA solvent ambiences at different temperature $(45,60$, $60^{\circ} \mathrm{C}$ ) for $5 \mathrm{~min}$ and then annealed at $100^{\circ} \mathrm{C}$ in $\mathrm{N}_{2}$ for $5 \mathrm{~min}$. The volume of the solvent dropped on the surface of the hot plate is $240 \mu \mathrm{L}$. During the second spin-coating process, $200 \mu \mathrm{L}$ solution of $\mathrm{CH}_{3} \mathrm{NH}_{3} \mathrm{I}$ in IPA $\left(8 \mathrm{mg} \mathrm{mL}^{-1}\right)$ was loaded on $\mathrm{PbI}_{2}$ films for $50 \mathrm{~s}$, which was spun at 4,000 $\mathrm{rpm}$ for $30 \mathrm{~s}$ and dried at $100^{\circ} \mathrm{C}$ in $\mathrm{N}_{2}$ or IPA solvent ambience (IPA-SA-SA) for $5 \mathrm{~min}$. The substrates were subsequently covered with $60 \mu \mathrm{L}$ of a $72.3 \mathrm{mg} \mathrm{mL}^{-1}$ solution of spiro-OMeTAD in $1 \mathrm{~mL}$ chlorobenzene with $28.8 \mu \mathrm{L}$ of added 4-tert-butylpyridine, $17.5 \mu \mathrm{L}$ of a stock solution of $520 \mathrm{mg} \mathrm{mL}^{-1}$ lithium bis(trifluoromethylsulphonyl)imide in acetonitrile and $29 \mu \mathrm{L}$ of $520 \mathrm{mg} \mathrm{mL}^{-1}$ tris (2-(1H-pyrazol-1-yl)-4-tert-butylpyridine) cobalt(III) bis (trifluoromethylsul- phonyl) imide in acetonitrile. This solution was spin-coated at $4,000 \mathrm{rpm}$ for $30 \mathrm{~s}$. Finally, $80 \mathrm{~nm}$ of a gold film was deposited using thermal evaporation.

\section{$\mathrm{CsPbI}_{3}$ films and solar cells fabrication}

The methods and processes for preparing FTO and c$\mathrm{TiO}_{2}$ were the same as the above-mentioned preparation method. $\mathrm{CsPbI}_{3}$ was synthesized using the one-step spin coating method. $124.8 \mathrm{mg}$ of CsI and $221.76 \mathrm{mg}$ of $\mathrm{PbI}_{2}$ were mixed in $1 \mathrm{~mL}$ of DMF. $66 \mu \mathrm{l}$ of HI solution (57\% wt) was added in this solution. After stirring more than $1 \mathrm{~h}, 60 \mu \mathrm{L}$ of $\mathrm{CsPbI}_{3}$ solution was spin-coated on the $\mathrm{FTO} / \mathrm{c}-\mathrm{TiO}_{2} / \mathrm{m}-\mathrm{TiO}_{2}$ substrate at $2,000 \mathrm{rpm}$ for $30 \mathrm{~s}$. Then this film was annealed in $\mathrm{N}_{2}$ or IPA solvent at $100^{\circ} \mathrm{C}$ for $10 \mathrm{~min}$. When fabricated $\mathrm{CsPbI}_{3}$ solar cells, the substrates were covered with a solution of spiro-OMeTAD that is the same as mentioned in previous part. This solution was spin-coated at 4,000 rpm for 30s. Finally, $80 \mathrm{~nm}$ of a gold film was deposited using thermal evaporation.

\section{Measurement and characterization}

$\mathrm{X}$-ray diffraction (XRD) diagrams were carried out using a Bede D1 system with $\mathrm{Cu}$ Ka radiation. Scanning electron microscopy (SEM) images were obtained using field emission fitting SEM (FEI-Inspect F50, Holland). Atomic force microscopy (AFM) images were measured by an AFM 5500 (Agilent). The ultraviolet-visible (UV-vis) absorption spectrum were measured by a UV-vis spectrophotometer (Schimadzu UV-3101 PC). For previous measurements, perovskite films were deposited on FTO/ c- $-\mathrm{TiO}_{2} / \mathrm{m}-\mathrm{TiO}_{2}$ substrates. And there were no spiro$\mathrm{OMeTAD}$ and $\mathrm{Au}$ layers. Current-voltage measurements were carried out using Keithley 2400 under AM 1.5G illuminations $\left(1,000 \mathrm{~W} \mathrm{~m}^{-2}\right)$ from a solar simulator (Newport Oriel Solar 3A Class AAA, 64023A). The AM $1.5 \mathrm{G}$ sun light was calibrated using a standard Si-solar cell (Oriel, VLSI standards). The active area of devices is 0.04 $\mathrm{cm}^{2}$. Electrochemical impedance spectroscopy (EIS) were measured with electrochemical workstation (CHI660d). The applied voltage perturbation had an AC amplitude of $35 \mathrm{mV}$ with a frequency range from $1 \mathrm{MHz}$ to $100 \mathrm{~Hz}$. The impedance parameters were simulated by fitting of impedance spectrum through Z-view software.

\section{RESULTS AND DISCUSSION}

The fabrication schematics of $\mathrm{CH}_{3} \mathrm{NH}_{3} \mathrm{PbI}_{3}$ prepared by the sequential solvent annealing method and $\mathrm{CsPbI}_{3}$ prepared by the one-step deposition method are shown in Fig. 1a, b. The sequential deposition process is based on the two-step deposition method reported by Grätzel's group [18]. A weakly coordinating solvent, in this case, IPA, is chosen because it has a poor solubility of lead ions and weak interaction between solvent molecules and perovskite precursors [42]. In the first part, $\mathrm{PbI}_{2}$ precursors were heated in the IPA solvent atmosphere at three different annealing temperatures $\left(45,60\right.$ and $\left.80^{\circ} \mathrm{C}\right)$. After the subsequent annealing in a nitrogen atmosphere at $100^{\circ} \mathrm{C}$, MAI was dropped and spin-coated on the $\mathrm{PbI}_{2}$ film to form $\mathrm{CH}_{3} \mathrm{NH}_{3} \mathrm{PbI}_{3}$ films. Perovskite films were then thermally annealed (TA) and dried in $\mathrm{N}_{2}$ atmosphere. The three processes of $\mathrm{CH}_{3} \mathrm{NH}_{3} \mathrm{PbI}_{3}$ films carried out at different solvent annealing temperatures are named as $45^{\circ} \mathrm{C}$ IPA-SA-TA, $60^{\circ} \mathrm{C}$ IPA-SA-TA and $80^{\circ} \mathrm{C}$ IPA-SA$\mathrm{TA}$, respectively. Control samples which were fabricated by conventional thermal annealing without any solvent named $45^{\circ} \mathrm{C}$ TA-TA.

Fig. 2a-d shows the AFM images of $\mathrm{PbI}_{2}$ films based on different annealing processes and annealing temperatures to study the roughness and morphology of these $\mathrm{PbI}_{2}$ films. Tapping mode was used in this measurement. In a 

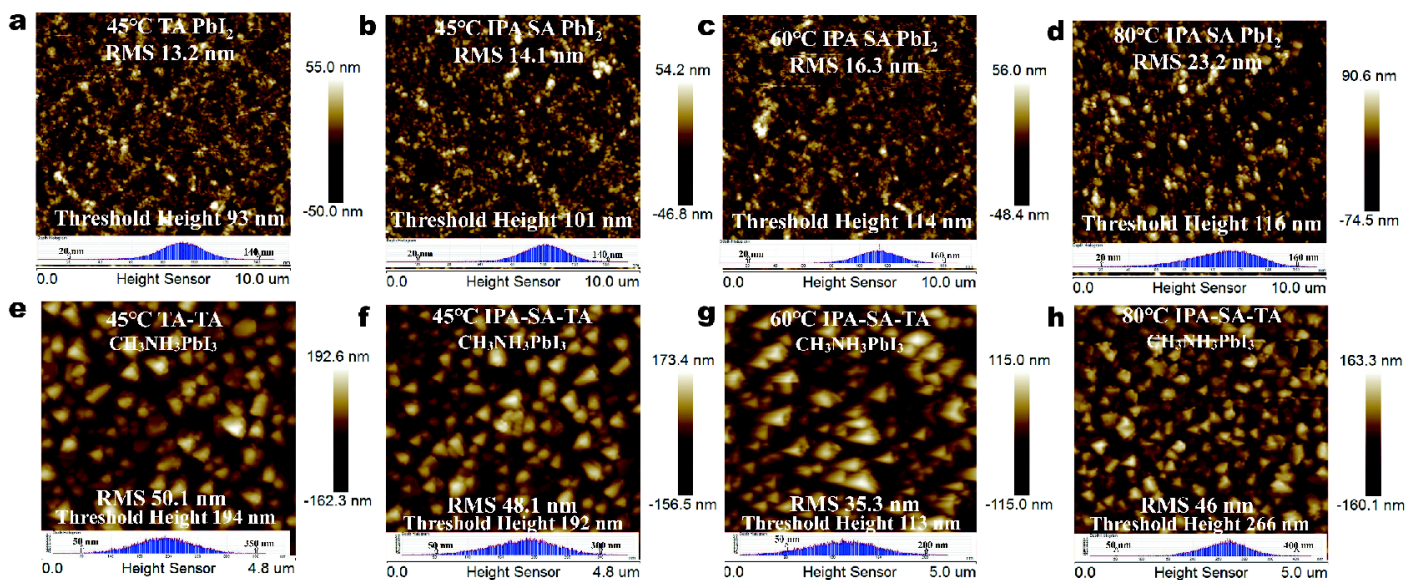

Figure 2 (a-d) AFM top views of $\mathrm{PbI}_{2}$ films treated by $45^{\circ} \mathrm{C}$ TA, $45^{\circ} \mathrm{C}$ IPA-SA, $60^{\circ} \mathrm{C}$ IPA-SA and $80^{\circ} \mathrm{C}$ IPA-SA. (e-h) AFM top views of $\mathrm{CH}_{3} \mathrm{NH}_{3} \mathrm{PbI}_{3}$ perovskite films treated by $45^{\circ} \mathrm{C}$ TA-TA, $45^{\circ} \mathrm{C}$ IPA-SA-TA, $60^{\circ} \mathrm{C}$ IPA-SA-TA, $80^{\circ} \mathrm{C}$ IPA-SA-TA.

previous study, we found the initial solvent annealing temperature greatly influenced the surface morphology of lead iodide films $[25,26]$. Here, in Fig. 2, the surface roughness of $\mathrm{PbI}_{2}$ was hardly affected by IPA solvent atmosphere at low annealing temperature. When the $\mathrm{PbI}_{2}$ was heated at $80^{\circ} \mathrm{C}$, the roughness increased from 13 to $23 \mathrm{~nm}$. Meanwhile, we found IPA SA could increase the average height of $\mathrm{PbI}_{2}$ grains. The threshold heights of $\mathrm{PbI}_{2}$ fabricated by the $45^{\circ} \mathrm{C}$ TA-TA, $45^{\circ} \mathrm{C}$ IPA-SA-TA, $60^{\circ}$ C IPA-SA-TA and $80^{\circ} \mathrm{C}$ IPA-SA-TA were $93,101,114$ and $116 \mathrm{~nm}$, respectively. This result illustrated that the $\mathrm{PbI}_{2}$ film had a higher roughness after the IPA SA process. Fig. 2e-h show the AFM images of $\mathrm{CH}_{3} \mathrm{NH}_{3} \mathrm{PbI}_{3}$ using $45^{\circ} \mathrm{C}$ TA-TA, $45^{\circ} \mathrm{C}$ IPA-SA-TA, $60^{\circ} \mathrm{C}$ IPA-SA-TA and $80^{\circ} \mathrm{C}$ IPA-SA-TA. The roughness measurement of the surface (RMS) of the above-described perovskite is 50 , 48, 35 and $46 \mathrm{~nm}$, respectively. Compared with the film prepared with $45^{\circ} \mathrm{C}$ TA-TA process, the threshold height of $\mathrm{CH}_{3} \mathrm{NH}_{3} \mathrm{PbI}_{3}$ films also decreased when $\mathrm{PbI}_{2}$ was annealed in IPA solvent at 45 or $60^{\circ} \mathrm{C}$. But the grain size of perovskite seemed increased through the IPA SA process.

Fig. 3a, $b$ show the SEM images of $\mathrm{CH}_{3} \mathrm{NH}_{3} \mathrm{PbI}_{3}$ films with $45^{\circ} \mathrm{C}$ TA-TA and $60^{\circ} \mathrm{C}$ IPA-SA-TA processes. The grain size of the $\mathrm{CH}_{3} \mathrm{NH}_{3} \mathrm{PbI}_{3}$ film based on $60^{\circ} \mathrm{C}$ IPASA-TA is much larger than that based on $45^{\circ} \mathrm{C}$ TA-TA process. Fig. $3 \mathrm{C}$ shows the grain size statistics of perovskite films (calculated by Nano Measurement software). The mean grain size of the perovskite films prepared by $45^{\circ} \mathrm{C}$ TA-TA and $60^{\circ} \mathrm{C}$ IPA-SA-TA is 204 and $372 \mathrm{~nm}$, respectively. This is because that the uneven and better crystalline $\mathrm{PbI}_{2}$ film might led to larger grain size of perovskite films and better reaction between perovskite precursors. Note that, perovskite films treated with $45^{\circ} \mathrm{C}$ TA-SA and $60^{\circ} \mathrm{C}$ IPA-SA-TA both have some pinholes or gaps on the surface. IPA SA significantly improved the optical absorption of $\mathrm{PbI}_{2}$ as shown in Fig. 3d. The absorption at $500 \mathrm{~nm}$ of $\mathrm{PbI}_{2}$ using IPA SA process was higher than that using TA process. For the $\mathrm{UV}$-vis absorption of $\mathrm{CH}_{3} \mathrm{NH}_{3} \mathrm{PbI}_{3}$ in Fig. $3 \mathrm{~d}$, the base line (the absorption at longer wave lengths than $800 \mathrm{~nm}$ ) of UV-vis absorption of $60^{\circ} \mathrm{C}$ IPA-SA-TA or $80^{\circ} \mathrm{C}$ IPASA-TA becomes lower, which indicates a more homogenous surface of perovskite films with less diffuse reflection [43]. Each sample shows a good light absorption of $\mathrm{CH}_{3} \mathrm{NH}_{3} \mathrm{PbI}_{3}$ in the range around $760 \mathrm{~nm}$. We marked the absorptions $(0.238,0.234,0.244$ and 0.262$)$ around $760 \mathrm{~nm}$ of $\mathrm{CH}_{3} \mathrm{NH}_{3} \mathrm{PbI}_{3}$ perovskite films prepared from $\mathrm{PbI}_{2}$ films using $45^{\circ} \mathrm{C}$ TA-TA, $45^{\circ} \mathrm{C}$ IPA-SA-TA, $60^{\circ} \mathrm{C}$ IPA-SA-TA and $80^{\circ} \mathrm{C}$ IPA-SA-TA processes. The $60^{\circ} \mathrm{C}$ IPA-SA-TA and $80^{\circ} \mathrm{C}$ IPA-SA-TA processes resulted in the better absorption of perovskite.

Fig. 3e shows the (001) peak of lead iodide at $12.6^{\circ}$. In comparison to $45^{\circ} \mathrm{C}$ TA-TA and $45^{\circ} \mathrm{C}$ IPA-SA-TA, the XRD peak corresponding to (001) plane of $\mathrm{PbI}_{2}$ becomes higher after IPA SA. It is obviously that IPA SA enhanced the crystallization of lead iodide. Both annealing atmosphere and temperature affect crystallization of lead iodide. The formation of lead iodide films not only depends on temperature, but also the movement of IPA molecules and recrystallization of $\mathrm{PbI}_{2}$. Meanwhile, this XRD peak becomes sharper and higher with the increase of annealing temperature when it was annealed in IPA solvent. This result confirmed that IPA could recrystallized $\mathrm{PbI}_{2}$ films in the process of solvent annealing. Furthermore, such an improved crystallinity of $\mathrm{PbI}_{2}$ has a double-sided effect. On one hand, it enhances the crystallization of 

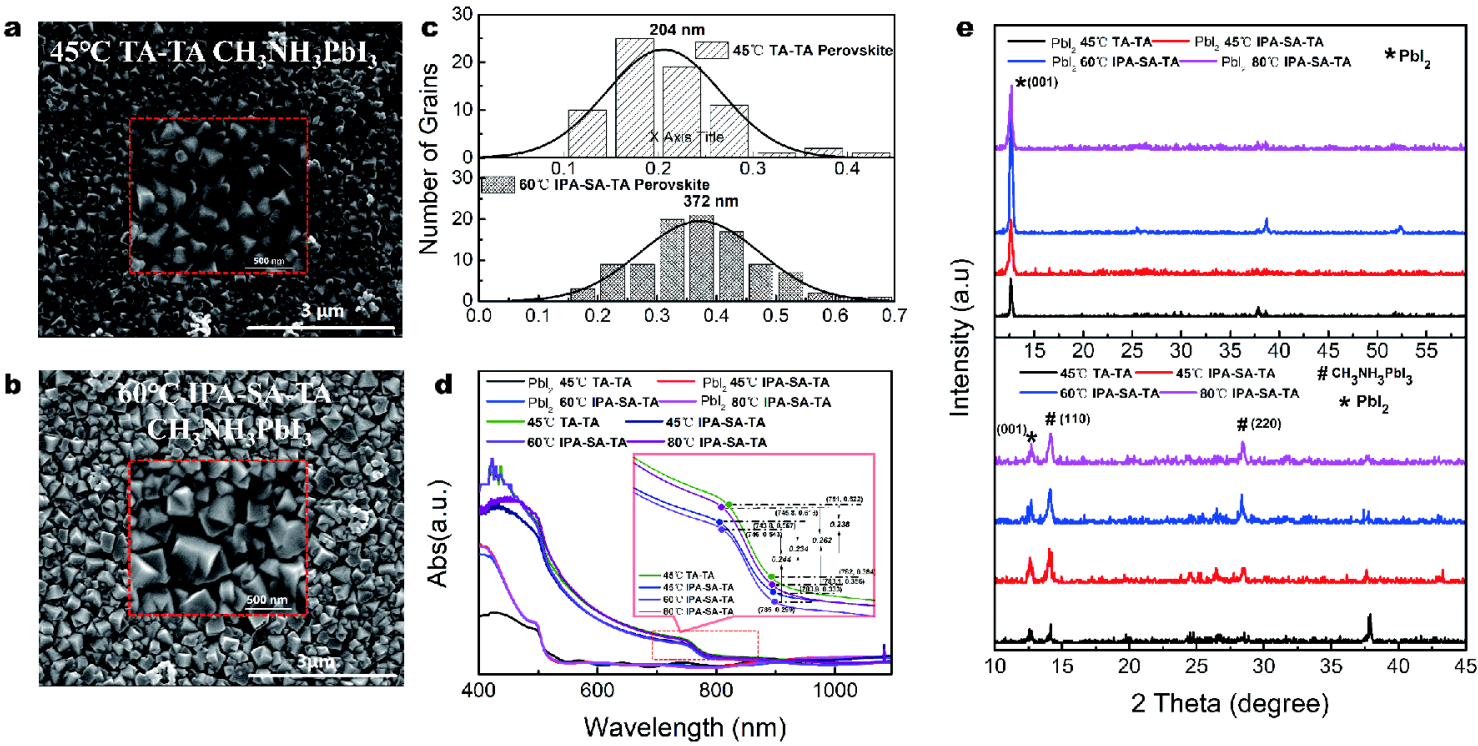

Figure 3 (a, b) SEM top views of perovskite films treated by $45^{\circ} \mathrm{C}$ TA-TA and $60^{\circ} \mathrm{C}$ IPA-SA-TA. (c) Grain size statistics of perovskite films based on $45^{\circ} \mathrm{C}$ TA-TA and $60^{\circ} \mathrm{C}$ IPA-SA-TA. (d, e) UV-vis absorption spectra and XRD patterns of $\mathrm{PbI}_{2}$ and $\mathrm{CH}_{3} \mathrm{NH}_{3} \mathrm{PbI}_{3}$ using $45^{\circ} \mathrm{C}$ TA-TA, $45^{\circ} \mathrm{C}$ IPA-SATA, $60^{\circ} \mathrm{C}$ IPA-SA-TA and $80^{\circ} \mathrm{C}$ IPA-SA-TA.

$\mathrm{CH}_{3} \mathrm{NH}_{3} \mathrm{PbI}_{3}$, and on the other hand, it retards the conversion of lead iodide into perovskite. The XRD measurements of $\mathrm{MAPbI}_{3}$ shown in Fig. 3e shows the denser and higher unreacted $\mathrm{PbI}_{2}$ peak of (001) at $12.4^{\circ}$ and the $\mathrm{MAPbI}_{3}(110)$ peak at $14.6^{\circ}$ were obtained from the improved crystalline $\mathrm{PbI}_{2}$. 2Theta-Omega mode was used in our measurement. Residual lead iodide may bring about a passivation effect in perovskite solar cells which could improve the performance of devices [44,45].

In order to study and observe the direct influences of $\mathrm{PbI}_{2}$ films based on different annealing processes on device performance, Fig. 4 shows the $J-V$ curves, distribution of PSCs parameters, EIS and plots of $-\mathrm{d} V / \mathrm{d} J$ versus $\left(J_{\mathrm{SC}}-J\right)^{-1}$ of $\mathrm{CH}_{3} \mathrm{NH}_{3} \mathrm{PbI}_{3}$ solar cells fabricated using different annealing processes for $\mathrm{PbI}_{2}$. $J_{\mathrm{SC}}$ and $V_{\mathrm{OC}}$ mean the short circuit current density and open circuit voltage, respectively. Fig. 4a shows the $J-V$ curves of perovskite solar cells fabricated from the $\mathrm{PbI}_{2}$ films based on different annealing processes. In the case of $\mathrm{PbI}_{2}$ with IPA SA, the PCE increases from $15.04 \%$ to $16.09 \%$ with the increased annealing temperature from $45^{\circ} \mathrm{C}$ to $60^{\circ} \mathrm{C}$, which is followed by a decrease to $13.18 \%$ with the annealing temperature of $80^{\circ} \mathrm{C}$. Meanwhile, the PCE of PSCs with the $45^{\circ} \mathrm{C}$ TA-TA process is $14.73 \%$ which is similar with the PCE of PSCs based on the $45^{\circ} \mathrm{C}$ IPA-SATA process. Fig. $4 \mathrm{~b}$ shows the distribution of the efficiency, $V_{\mathrm{OC}}, \mathrm{FF}$ (fill factor) and $J_{\mathrm{SC}}$ of the devices with $45^{\circ}$ C TA-TA and IPA-SA-TA $\left(45,60\right.$ and $\left.80^{\circ} \mathrm{C}\right)$ processes.
Compared with PSCs made from the $45^{\circ} \mathrm{C}$ TA-TA process, the statistical distributions of device performance is even more uniform and the value of $J_{\mathrm{SC}}$ and PCE become higher when the PSCs were treated by $45^{\circ} \mathrm{C}$ IPA-SA-TA or $60^{\circ} \mathrm{C}$ IPA-SA-TA. The solar cell with $80^{\circ} \mathrm{C}$ IPA-SA-TA got the worst performance. As reported in previous articles, several optoelectronic characteristics, such as film trap density, lifetime and EIS can be used to illustrate the improvement of morphology and ability of perovskite films [46-49]. In our study, SEM, EIS measurement and ideal factor characterization have been employed. To further investigate the photovoltaic performance, Fig. $4 \mathrm{c}$ shows the plots of $-\mathrm{d} V / \mathrm{d} J$ versus $\left(J_{\mathrm{sC}}-J\right)^{-1}$ and the linear fitting curves to calculate the ideal factor of the heterojunction [50]. The formula is expressed as: $-\mathrm{d} V / \mathrm{d} J=$ $\left(N k_{\mathrm{B}} T / \mathrm{e}\right)\left(J_{\mathrm{SC}} J\right)^{-1}+R_{\mathrm{S}}$, where $R_{\mathrm{S}}$ is the series resistance, $J_{\mathrm{SC}}$ is the short circuit current density, $J$ is the current density flowing through the external load, $N$ is the ideality factor of a heterojunction, $k_{\mathrm{B}}$ is the Boltzmann constant, $T$ is the absolute temperature, $\mathrm{e}$ is the elementary charge, and $V$ is the direct current (DC) bias voltage applied to the cell. For a general heterojunction solar cell, $N$ is always between 1.3 and 2. The PSC based on $60^{\circ} \mathrm{C}$ IPA-SA-TA achieves the best $N$ value of 2.7 which is the closest to 2 . The fitting curve of this sample also shows the smallest slope. The solar cell agrees better with the ideal heterojunction solar cell. The $60^{\circ} \mathrm{C}$ IPA-SA-TA process effectively improved the junction ability of perovskite films. 

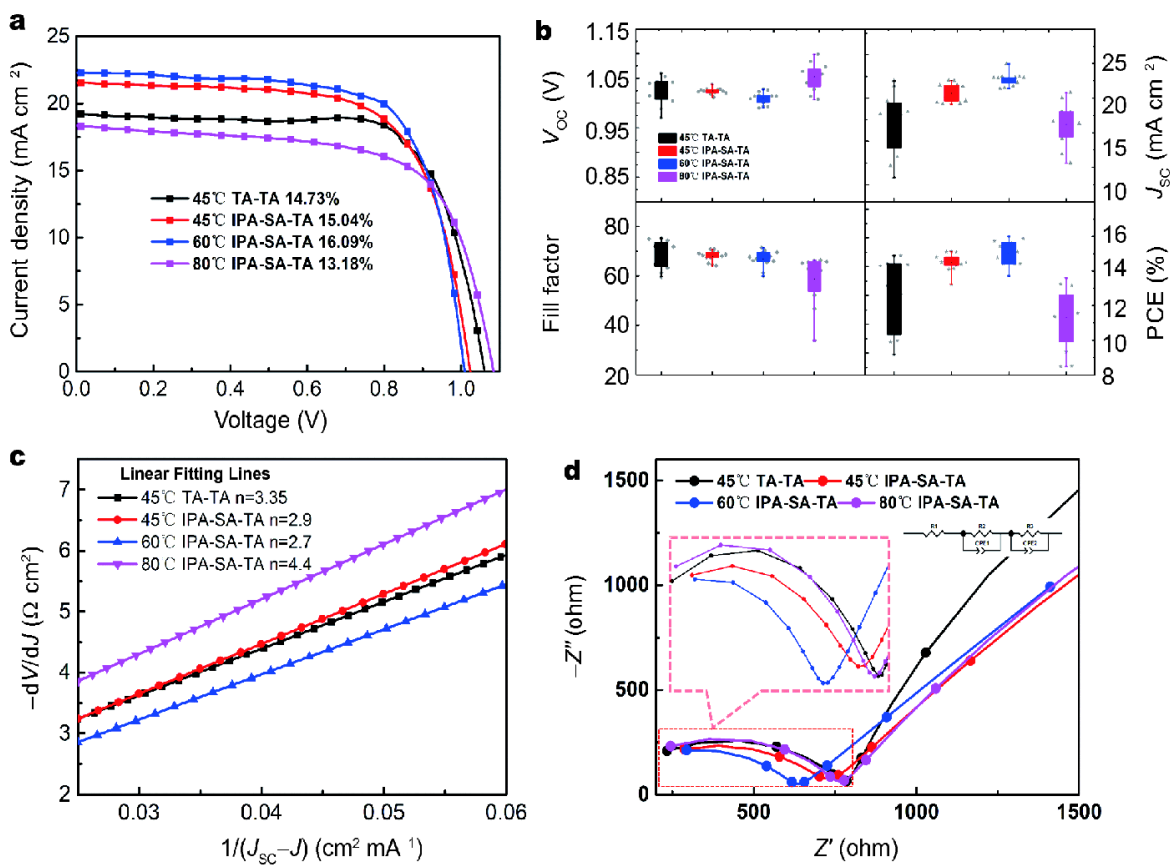

Figure 4 (a), (c, d) $J-V$ curves, plots of $-\mathrm{d} V / \mathrm{d} J$ versus $\left(J_{\mathrm{SC}}-J\right)^{-1}$ and the linear fitting curves of PSCs and EIS of the solar cell samples with $45^{\circ} \mathrm{C}$ TA-TA, $45^{\circ} \mathrm{C}$ IPA-SA-TA, $60^{\circ} \mathrm{C}$ IPA-SA-TA and $80^{\circ} \mathrm{C}$ IPA-SA-TA. (b) Distribution of the $J_{\mathrm{SC}}, V_{\mathrm{OC}}$, FF and efficiency of the devices with different annealing processes $\left(45^{\circ} \mathrm{C}\right.$ TA-TA, $45^{\circ} \mathrm{C}$ IPA-SA-TA, $60^{\circ} \mathrm{C}$ IPA-SA-TA and $80^{\circ} \mathrm{C}$ IPA-SA-TA).

Table 1 By fitting with a simple equivalent circuit model, $R_{1}, R_{2}$ and $R_{3}$ of PSCs using $45^{\circ} \mathrm{C}$ TA-TA, $45^{\circ} \mathrm{C}$ IPA-SA-TA, $60^{\circ} \mathrm{C}$ IPA-SA-TA and $80^{\circ} \mathrm{C}$ IPA-SA-TA processes

\begin{tabular}{ccccc}
\hline$R /$ Device & Wo IPA SA & IPA $45^{\circ} \mathrm{C}$ & IPA $60^{\circ} \mathrm{C}$ & IPA $80^{\circ} \mathrm{C}$ \\
\hline$R_{1}(\Omega)$ & 57 & 43 & 25 & 44 \\
$R_{2}(\Omega)$ & 726 & 675 & 591 & 713 \\
$R_{3}(\Omega)$ & 8331 & 17107 & 60925 & 11263 \\
\hline
\end{tabular}

Fig. 4d exhibits EIS to study the charge transport ability in these PSCs [51,52]. Two semicircles were obtained in the Nyquist plots. By fitting with a simple equivalent circuit model, $R_{1}$ represents the electrolyte resistance, $R_{2}$ represents the transfer resistance which is obtained from the first semicircle in the high frequency range, and $R_{3}$ from second arc is related to the recombination resistance. Obviously, the curve of the transfer resistance for the sample treated by the $60^{\circ} \mathrm{C}$ IPA-SA-TA process shows a smaller value of $591 \Omega$ than that for the sample treated by other annealing processes in Table 1. This should be due to a better charge-transfer ability. The recombination resistance of the PSC treated by $60^{\circ} \mathrm{C}$ IPASA-TA is the largest. A larger recombination resistance indicates a lower recombination loss that is also attributed to a suitable amount of residual lead iodide or better crystallinity. The Abs, XRD, PCE, EIS and ideal factor analysis show that the annealing of $\mathrm{PbI}_{2}$ significantly affects the crystallinity of perovskite films. Acetone, a kind of solvent with low solubility of $\mathrm{Pb}^{2+}$ and low boiling point, was used in a control experiment group. Fig. S8 shows $\mathrm{Abs}$ and $\mathrm{XRD}$ of $\mathrm{PbI}_{2}$ and $\mathrm{CH}_{3} \mathrm{NH}_{3} \mathrm{PbI}_{3}$ based on acetone solvent annealing processes. We found acetone showed the similar effect with IPA on the recrystallization of $\mathrm{PbI}_{2}$ films. This result confirmed weak coordinating solvent could effectively rearrange $\mathrm{PbI}_{2}$ crystals and affect quality of perovskite films.

For lead iodide, IPA atmosphere effectively modified the surface morphology and improved the crystallinity through poor solubility of lead iodide and weak coordination ability. Recrystallization process of lead iodide occurred under the solvent annealing conditions. Annealing temperature and solvent atmosphere function together to regulate this process. A dense but uneven $\mathrm{PbI}_{2}$ film was achieved and led to larger grain sizes of the perovskite films and better reaction between perovskite precursors. However, if the perovskite grain growth could not be well controlled, gaps or pinholes are easy to form.

We employed the second IPA SA process for $\mathrm{CH}_{3} \mathrm{NH}_{3} \mathrm{PbI}_{3}$ films fabricated from $\mathrm{PbI}_{2}$ with $60^{\circ} \mathrm{C}$ IPA SA and the IPA SA process $\left(100^{\circ} \mathrm{C}\right)$ for $\mathrm{CsPbI}_{3}$ films in the 



Figure 5 (a, b) AFM top view and SEM top view images of $\mathrm{CH}_{3} \mathrm{NH}_{3} \mathrm{PbI}_{3}$ treated by $60^{\circ} \mathrm{C}$ IPA-SA-SA process. (c, d) UV-vis absorption spectra and XRD patterns of perovskite using $60^{\circ} \mathrm{C}$ IPA-SA-SA process compared with that using $60^{\circ} \mathrm{C}$ IPA-SA-TA.

one-step deposition process, as shown in Fig. 1. The samples are referred as $60^{\circ} \mathrm{C}$ IPA-SA-SA and IPA-SA$\mathrm{CsPbI}$, respectively. For our control samples, $\mathrm{CsPbI}_{3}$ films were only annealed in $\mathrm{N}_{2}$ at $100^{\circ} \mathrm{C}$ for $10 \mathrm{~min}$ (TA$\mathrm{CsPbI}_{3}$ ).

Fig. $5 \mathrm{a}$ shows the AFM image of $\mathrm{CH}_{3} \mathrm{NH}_{3} \mathrm{PbI}_{3}$ films using the $60^{\circ} \mathrm{C}$ IPA-SA-SA processes. The RMS of the $\mathrm{CH}_{3} \mathrm{NH}_{3} \mathrm{PbI}_{3}$ film with $60^{\circ} \mathrm{C}$ IPA-SA-SA process is $36 \mathrm{~nm}$. IPA SA process for $\mathrm{CH}_{3} \mathrm{NH}_{3} \mathrm{PbI}_{3}$ resulted in a more homogeneous interface of perovskite compared with other annealing processes. Therefore, the $\mathrm{CH}_{3} \mathrm{NH}_{3} \mathrm{PbI}_{3}$ film exhibited lower roughness and more uniform grain distribution. Fig. $5 \mathrm{~b}$ shows the SEM image of $\mathrm{CH}_{3} \mathrm{NH}_{3} \mathrm{PbI}_{3}$ films with $60^{\circ} \mathrm{C}$ IPA-SA-SA process. When the $60^{\circ} \mathrm{C}$ IPA-SA-SA process was used, the grain size of the perovskite film became smaller but the perovskite grains became denser compared to that with $60^{\circ} \mathrm{C}$ IPASA-TA. This is an interesting phenomenon because solvent annealing was observed to enlarge perovskite domains and reduce the number of grain boundaries [33,37-39]. Here, the weakly coordinating solvent annealing for $\mathrm{CH}_{3} \mathrm{NH}_{3} \mathrm{PbI}_{3}$ films leads to uniform grain size and a homogeneous surface with few pinholes. The grain size statistics of perovskite films shows the mean grain size of the perovskite films prepared by $60^{\circ} \mathrm{C}$ IPA-SA-SA is $218 \mathrm{~nm}$. Additionally, the trend line of grain size sta- tistic of perovskite based on $60^{\circ} \mathrm{C}$ IPA-SA-SA is sharper and higher than that of perovskites treated by $45^{\circ} \mathrm{C}$ TATA and $60^{\circ} \mathrm{C}$ IPA-SA-TA. This means that the grain size of this film is more concentrated. Thus, we found there is a more uniform distribution of $\mathrm{CH}_{3} \mathrm{NH}_{3} \mathrm{PbI}_{3}$ nuclei in the formation process of $60^{\circ} \mathrm{C}$ IPA-SA-SA.

Fig. $5 c$, $d$ show the UV-vis absorption and XRD analysis of $\mathrm{CH}_{3} \mathrm{NH}_{3} \mathrm{PbI}_{3}$ films treated with the $60^{\circ} \mathrm{C}$ IPA-SASA process compared with that with $60^{\circ} \mathrm{C}$ IPA-SA-TA. The absorption slope around $\sim 760 \mathrm{~nm}$ of perovskite films obtained via $60^{\circ} \mathrm{C}$ IPA-SA-SA is similar with that of the perovskite films prepared using $60^{\circ} \mathrm{C}$ IPA-SA-TA. Enlarging the image of absorption around $760 \mathrm{~nm}$ (from 700 to $800 \mathrm{~nm}$ ), the perovskite film with $60^{\circ} \mathrm{C}$ IPA-SA-SA shows a better absorption. This is consistent with the above AFM and SEM measurements. Through the IPA SA for $\mathrm{CH}_{3} \mathrm{NH}_{3} \mathrm{PbI}_{3}$, the (110) peak of $\mathrm{CH}_{3} \mathrm{NH}_{3} \mathrm{PbI}_{3}$ at $14.6^{\circ}$ is sharper and higher, as shown in Fig. $5 \mathrm{~d}$. The (110) peak strength of perovskite based on $60^{\circ} \mathrm{C}$ IPA-SA-SA is 147.73, which is higher than that (113.64) based on $60^{\circ} \mathrm{C}$ IPA-SA-TA. Meanwhile, the (001) peak of $\mathrm{PbI}_{2}$ at $12.4^{\circ}$ is decreased because of the reduced amount of residual lead iodide. In our experiment, the detail interaction between IPA and the annealing materials was discussed. Firstly, IPA solvent vapor could provide a wet atmosphere so that the precursor ions and molecules could diffuse a longer 

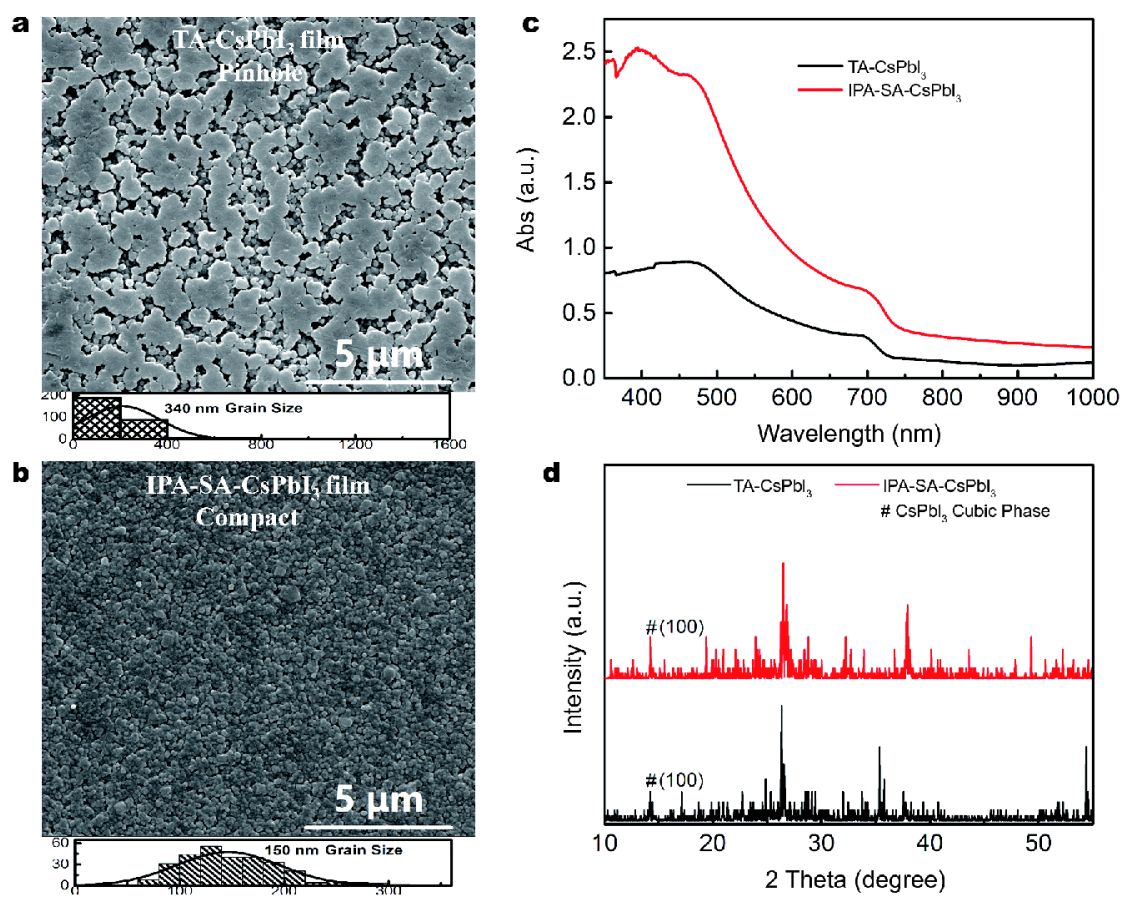

Figure 6 (a, b) SEM top views of $\mathrm{CsPbI}_{3}$ films treated by TA-CsPbI and IPA-SA-CsPbI . (c, d) UV-vis absorption spectra and XRD patterns of perovskite using $\mathrm{TA}-\mathrm{CsPbI} \mathrm{P}_{3}$ and IPA-SA-CsPbI .

distance than in thermal annealing. So the grain size and morphology were improved via IPA SA. Secondly, IPA vapor seriously affected the residual solvent in precursor crystal. Residual solvent is always strong Lewis additives, such as DMF, DMSO. These residual solvents have a very strong solubility of lead iodide or other perovskite precursors. In this process, IPA vapor modified the volume of residual solvent and affected the dissolution-recrystallization process for perovskite or perovskite precursor. Thirdly, IPA has a higher solubility for MAI than for lead iodide which could reduce the volatility of MAI and promote the growth of crystals. We also employed IPA SA to fabricate $\mathrm{CsPbI}_{3}$ films. A planar structure was made in our experiment. With different annealing processes, $\mathrm{CsPbI}_{3}$ films with different levels of compactness and grain sizes were obtained. In 2016, Luo et al. [46] used IPA dipping treatment for fabricating stable $\mathrm{CsPbI}_{3}$ solar cells and achieved a PCE of $4.13 \%$. IPA SA process carried out in this research was different from the dipping process. IPA solvent vapor reacted strongly with nuclei on the surface of $\mathrm{CsPbI}_{3}$ films and modified the amount of residual solvent in films. We emphasized the research of the growth mechanism of perovskite in weak coordinating solvent environment and the effect of the annealing atmosphere on film crystallization. The re- crystallization of $\mathrm{CsPb}_{3}$ was ascribed to a combination of annealing and IPA atmosphere. Meanwhile, based on Luo's article [46], we recognized IPA could stabilize $\alpha$ phase of $\mathrm{CsPbI}_{3}$ through affecting the transformation from $\mathrm{Cs}_{4} \mathrm{PbI}_{6}$ immediate to $\mathrm{CsPbI}_{3}$. Fig. $6 \mathrm{a}, \mathrm{b}$ show the SEM images of $\mathrm{CsPbI}_{3}$ films fabricated by the TA-CsPbI and IPA-SA-CsPbI ${ }_{3}$. Note that, we tested these films after a period of time after films deposition. According to the report of Jin's group [53,54], there should be orthorhombic phase $\mathrm{CsPbI}_{3}$ with large grain size shown in Fig. 6a. But according to our XRD result shown in Fig. 6d, $\mathrm{CsPbI}_{3}$ has not totally degraded. Through the IPA SA, the $\mathrm{CsPbI}_{3}$ film became more compact with uniform grains. There are more nuclei in the $\mathrm{CsPbI}_{3}$ film obtained using IPA SA process. The grain size statistics of $\mathrm{CsPbI}_{3}$ films fabricated via $\mathrm{TA}-\mathrm{Cs} \mathrm{PbI}_{3}$ or IPA-SA-CsPbI $\mathrm{I}_{3}$ processes shows the mean grain size of $\mathrm{CsPbI}_{3}$ films is $340 \mathrm{~nm}$ and $150 \mathrm{~nm}$, respectively. The orthorhombic phase also influence the grain size of $\mathrm{CsPbI}_{3}$. The mean grain size of the $\mathrm{CsPbI}_{3}$ film with $\mathrm{TA}-\mathrm{CsPbI}{ }_{3}$ is more than twice the size of the $\mathrm{CsPbI}_{3}$ film with IPA-SA-CsPbI ${ }_{3}$. Meanwhile, the $\mathrm{CsPbI}_{3}$ film with IPA-SA-CsPbI ${ }_{3}$ shows a more concentrated distribution of grains. The differences of grain size and film coverage between $\mathrm{CsPbI}_{3}$ films based on the thermal annealing process and IPA SA process are very 




Figure 7 Photos of $\mathrm{CsPbI}_{3}$ films using TA and IPA-SA processes changed with time.

obvious.

Fig. $6 \mathrm{c}$ shows the UV-vis absorption of $\mathrm{CsPbI}_{3}$ films. It is obvious that the absorption of the $\mathrm{CsPbI}_{3}$ film with IPA-SA-CsPbI ${ }_{3}$ around $720 \mathrm{~nm}$ (the band gap of $\alpha-\mathrm{CsPI}_{3}$ is $1.73 \mathrm{eV}$, corresponding to the optical absorption of $717 \mathrm{~nm}$ ) is much higher than that with $\mathrm{TA}-\mathrm{CsPbI}_{3}$. This UV-vis absorption result is in good agreement with the SEM images. Better absorption of the $\mathrm{CsPbI}_{3}$ film with IPA-SA-CsPbI ${ }_{3}$ should be owing to the compacter morphology of $\mathrm{CsPbI}_{3}$ films. Note that, the baseline of the $\mathrm{CsPbI}_{3}$ sample with IPA-SA-CsPbI ${ }_{3}$ is higher than that with the $\mathrm{TA}-\mathrm{CsPbI}{ }_{3}$ process. This is caused by stronger light scattering due to the rough surface of the $\mathrm{CsPbI}_{3}$ film. Therefore, the IPA SA process can also be used to effectively modify the surface morphology and roughness of $\mathrm{CsPbI}_{3}$ films. Furthermore, as shown in Fig. 6d, the main XRD peak (100) of cubic $\mathrm{CsPbI}_{3}\left(\alpha-\mathrm{CsPbI}_{3}\right)$ is sharper in the case of IPA SA. This suggests that the IPA SA results in better crystallization of $\mathrm{CsPbI}_{3}$ films with a small grain size and good compactness.

We found this weakly coordinating solvent annealing process is a favorable way to control the grain size and enhance the compactness and the quality of both $\mathrm{CH}_{3} \mathrm{NH}_{3} \mathrm{PbI}_{3}$ and $\mathrm{CsPbI}_{3}$ films. The IPA SA process for both $\mathrm{CH}_{3} \mathrm{NH}_{3} \mathrm{PbI}_{3}$ and $\mathrm{CsPbI}_{3}$ films creates more nucleation centers and these centers were more evenly distributed. We recognized the IPA vapor could slow down the volatilization of MAI and residual original solvent, which made the nucleation distribution more uniform in annealing of perovskite. The dissolution-recrystallization process could be well regulated. Different from strongly coordinating solvent (DMF, DMSO, GBL, etc.), weakly coordinating solvent annealing for perovskite could more effectively modify the morphology and affect the initial nucleation during film formation instead of expanding nuclei from the original strongly coordinating solvent. This may be attributed to the abilities of weakly coordinating solvent which has a poor solubility of lead ions, weak donating electron ability, good volatility and so on.

Interestingly, the IPA SA process is also helpful in improving the stability of the $\mathrm{CsPbI}_{3}$ films. We put $\mathrm{CsPbI}_{3}$ samples with the TA-CsPbI ${ }_{3}$ or IPA-SA-CsPbI ${ }_{3}$ process in an atmospheric environment at room temperature. The humidity was in the range from $40 \%$ to $80 \%$. The photographs of $\mathrm{CsPbI}_{3}$ films over time (from 0 to $280 \mathrm{~min}$ ) are shown in Fig. 7. At the beginning, the color of $\mathrm{CsPbI}_{3}$ based on the IPA-SA-CsPbI ${ }_{3}$ process was blacker than that based on the $\mathrm{TA}-\mathrm{CsPb}_{3}$ process. After being exposed to air for only $10 \mathrm{~min}$, the $\mathrm{TA}-\mathrm{Cs} \mathrm{PbI}_{3}$ perovskite film had a significant degradation or phase change. The color of $\mathrm{CsPbI}_{3}$ changed from brown to light yellow. However, the IPA-SA TA-CsPbI ${ }_{3}$ perovskite film was very stable and remains black. The phase change of the samples with the $\mathrm{TA}-\mathrm{Cs} \mathrm{PbI}_{3}$ process was more severe with time, and the $\mathrm{CsPbI}_{3}$ film became more transparent. After $220 \mathrm{~min}$, the $\mathrm{CsPbI}_{3}$ film with $\mathrm{TA}-\mathrm{CsPbI}_{3}$ underwent completely phase change, but there was still some residual $\alpha-\mathrm{CsPb}_{3}$ left in the $\mathrm{CsPbI}_{3}$ film with the IPA-SA-CsPbI ${ }_{3}$ process. Therefore, the IPA-SA-CsPbI ${ }_{3}$ process could effectively improve the stability and control the grain size of the $\mathrm{CsPbI}_{3}$ film. Note that we found DMF solvent annealing could dissolve the films because of its strong coordinating ability and polarity. So strong coordinating solvent were 

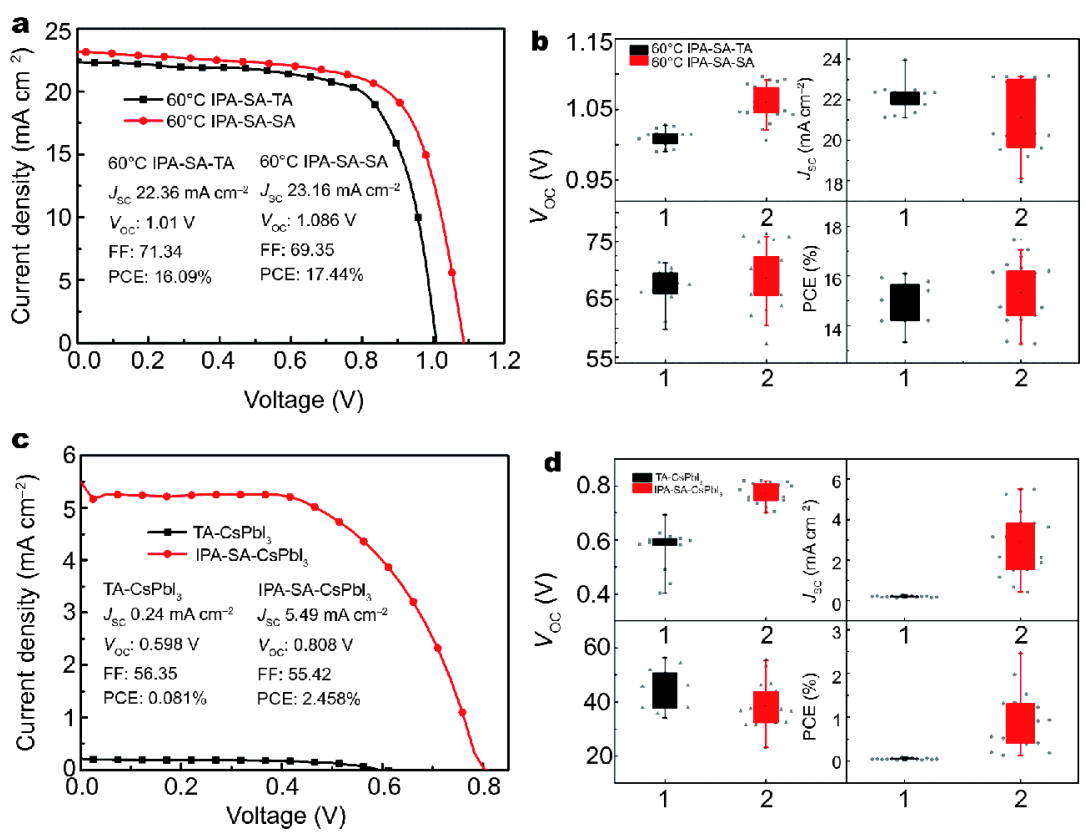

Figure 8 (a, b) $J-V$ curves and distribution of the $J_{\mathrm{SC}}, V_{\mathrm{OC}}$, FF and efficiency of PSCs $\left(\mathrm{CH}_{3} \mathrm{NH}_{3} \mathrm{PbI}_{3}\right)$ with $60^{\circ} \mathrm{C}$ IPA-SA-SA process and $60^{\circ} \mathrm{C}$ IPA-SATA process. (c, d) $J-V$ curves and distribution of the $J_{\mathrm{SC}}, V_{\mathrm{OC}}$, FF and efficiency of $\mathrm{CsPbI}_{3}$ solar cells with IPA-SA-CsPbI ${ }_{3}$ and $\mathrm{TA}^{-\mathrm{CsPbI}}{ }_{3}$ process.

not suitable for the solvent annealing for $\mathrm{CsPb}_{3}$ films.

Fig. 8a shows the $J-V$ curves of the PSCs fabricated by the $60^{\circ} \mathrm{C}$ IPA-SA-TA process and the $60^{\circ} \mathrm{C}$ IPA-SA-SA process. The performance of the device was improved by this second solvent annealing process. PSCs using the $60^{\circ} \mathrm{C}$ IPA-SA-SA process exhibited the best PCE of $17.4 \%$. In our measurements, reverse scan was carried out, where the number of sweep points is 100 and the dwell time is $30 \mathrm{~ms}$. The integrated photocurrent estimated from the EQE curve (Fig. S5) is in good agreement with that measured from the IV characteristics shown in Fig. 8a. The IPA SA process for the $\mathrm{CH}_{3} \mathrm{NH}_{3} \mathrm{PbI}_{3}$ film greatly improved the performance of the PSCs. Fig. $8 \mathrm{~b}$ shows the distribution of the PCE, $V_{\mathrm{OC}}, \mathrm{FF}$ and $J_{\mathrm{SC}}$ of the devices treated by $60^{\circ} \mathrm{C}$ IPA-SA-TA and $60^{\circ} \mathrm{C}$ IPA-SA-SA. It is clear that $60^{\circ} \mathrm{C}$ IPA-SA-SA results in better $V_{\mathrm{OC}}$ and PCE. The theoretical (maximum) $V_{\mathrm{OC}}$ of a solar cell is the energy gap between the Fermi level of the electron transporter materials and the HOMO of the donor. But the energy loss at interfaces and in perovskite films also influence $V_{\mathrm{OC}}$. Through IPA SA process, morphology, light absorption and crystallization of perovskite films were successfully improved. The reduced energy loss and improved carriers transport ability should be the reason for the increased PCE and $V_{\mathrm{OC}}$. As shown in Fig. S3, a slight hysteresis was observed from the $\mathrm{CH}_{3} \mathrm{NH}_{3} \mathrm{PbI}_{3}$ PSCs with $60^{\circ} \mathrm{C}$ IPA-SA-SA. However, a strong hysteresis behavior was shown from $\mathrm{CsPbI}_{3}$ solar cells. This is due to the different device structures and film quality of $\mathrm{CH}_{3} \mathrm{NH}_{3} \mathrm{PbI}_{3}$ and $\mathrm{CsPbI}_{3}$ in our research. But the aim of this work is to study the growth mechanism of perovskite films treated by IPA SA process. The previous SEM, XRD, UV-vis and other characterizations consistently confirmed that IPA SA was conductive to the crystallization and the growth of perovskite films.

Fig. $8 \mathrm{c}$ shows the $J-V$ curves of $\mathrm{CsPbI}_{3}$ PSCs using the IPA-SA-CsPbI ${ }_{3}$ process and $\mathrm{TA}-\mathrm{Cs} \mathrm{PbI}_{3}$ process. Under illumination intensity of $100 \mathrm{~mW} \mathrm{~cm}{ }^{-2}$, the best $\mathrm{CsPbI}_{3}$ device based on the IPA SA exhibits a $J_{\mathrm{SC}}$ of $5.48 \mathrm{~mA}$ $\mathrm{cm}^{-2}$, a $V_{\mathrm{OC}}$ of $808 \mathrm{mV}$, and a $\mathrm{FF}$ of 0.554 , resulting in a PCE of $2.5 \%$ (reverse scan, the dwell time is $10 \mathrm{~ms}$ ). However, the best $\mathrm{CsPbI}_{3}$ solar cells based on the TA process exhibits a $J_{\mathrm{SC}}$ of $0.24 \mathrm{~mA} \mathrm{~cm}^{-2}$, a $V_{\mathrm{OC}}$ of $598 \mathrm{mV}$, and a FF of 0.563 , resulting in a PCE as low as $0.08 \%$. Fig. $8 \mathrm{~d}$ shows the distribution of the PCE, $V_{\mathrm{OC}}, \mathrm{FF}$ and $J_{\mathrm{SC}}$ of the $\mathrm{CsPbI}_{3}$ devices treated by TA-CsPbI ${ }_{3}$ and IPA-SA$\mathrm{CsPbI}_{3}$. We found $V_{\mathrm{OC}}, J_{\mathrm{SC}}$ and PCE were significantly increased for the IPA-SA-CsPbI ${ }_{3}$ process. The effective improvement of the crystallinity and compactness of $\mathrm{CsPbI}_{3}$ films is the reason for the enhancement of photoelectric performance. In addition to the properties of the perovskite itself, the additives of hole transport material (HTM), preservation environment, etc., all affected the stability of the device. To study the stability, the $J-V$ 
curves of $\mathrm{CsPbI}_{3}$ based solar cells prepared by IPA-SA process within $100 \mathrm{~h}$ in dark are shown in Fig. S7 [55,56]. Although the stability of $\mathrm{CsPbI}_{3}$ films were improved by IPA-SA process, the PCE of $\mathrm{CsPbI}_{3}$ PSC decreased very quickly.

\section{CONCLUSIONS}

We studied the effect of the IPA SA process on the properties and performances of $\mathrm{PbI}_{2}$ and $\mathrm{CH}_{3} \mathrm{NH}_{3} \mathrm{PbI}_{3}$ films in the sequential deposition method. By using the IPA SA process, the interface morphology, crystallinity and grain size of the $\mathrm{PbI}_{2}$ and $\mathrm{CH}_{3} \mathrm{NH}_{3} \mathrm{PbI}_{3}$ films were successfully modified. We proposed that the IPA SA process could improve the performance and morphology of $\mathrm{CH}_{3} \mathrm{NH}_{3} \mathrm{PbI}_{3}$ films via weak modification ability and the effect on initial nucleation during film formation. $\mathrm{CH}_{3} \mathrm{NH}_{3} \mathrm{PbI}_{3}$ solar cells fabricated using the $60^{\circ} \mathrm{C}$ IPASA-SA process exhibited a best photoelectric conversion efficiency of $17.4 \%$. At the same time, this IPA SA process was also effective in the fabrication of $\mathrm{CsPbI}_{3}$. This weakly coordinating solvent process greatly enhanced the stability and photoelectric conversion performance of $\mathrm{CsPbI}_{3}$ solar cells at room temperature. The stable $\mathrm{CsPbI}_{3}$ solar cell with a PCE of $2.48 \%$ was attained. The weakly coordinating solvent annealing process presented here reveals the perovskite growth mechanism and nucleation kinetics. We believe this study is meaningful for the better preparation and application of perovskites.

\section{Received 29 January 2018; accepted 27 March 2018;} published online 20 April 2018

1 Kojima A, Teshima K, Shirai Y, et al. Organometal halide perovskites as visible-light sensitizers for photovoltaic cells. J Am Chem Soc, 2009, 131: 6050-6051

2 Yang WS, Park BW, Jung EH, et al. Iodide management in formamidinium-lead-halide-based perovskite layers for efficient solar cells. Science, 2017, 356: 1376-1379

3 Liao HC, Tam TLD, Guo P, et al. Dopant-free hole transporting polymers for high efficiency, environmentally stable perovskite solar cells. Adv Energy Mater, 2016, 6: 1600502

4 Zheng D, Huang W, Fan P, et al. Preparation of reduced graphene oxide: $\mathrm{ZnO}$ hybrid cathode interlayer using in situ thermal reduction/annealing for interconnecting nanostructure and its effect on organic solar cell. ACS Appl Mater Interfaces, 2017, 9: 48984907

5 Zhao D, Ke W, Grice CR, et al. Annealing-free efficient vacuumdeposited planar perovskite solar cells with evaporated fullerenes as electron-selective layers. Nano Energy, 2016, 19: 88-97

6 Tong X, Wang Z. Ferroelectric properties and applications of hybrid organic-inorganic perovskites. J Electro Sci Tech, 2017, 15(4): 326-332

7 Paek S, Schouwink P, Athanasopoulou EN, et al. From nano- to micrometer scale: the role of antisolvent treatment on high per- formance perovskite solar cells. Chem Mater, 2017, 29: 3490-3498

8 Dong F, Guo Y, Xu P, et al. Hydrothermal growth of $\mathrm{MoS}_{2} / \mathrm{Co}_{3} \mathrm{~S}_{4}$ composites as efficient Pt-free counter electrodes for dye-sensitized solar cells. Sci China Mater, 2017, 60: 295-303

9 Li L, Chen Y, Liu Z, et al. The additive coordination effect on hybrids perovskite crystallization and high-performance solar cell. Adv Mater, 2016, 28: 9862-9868

10 Chen H, Liu D, Wang Y, et al. Enhanced performance of planar perovskite solar cells using low-temperature solution-processed $\mathrm{Al}$ Doped $\mathrm{SnO}_{2}$ as electron transport layers. Nanoscale Res Lett, 2017, 12: 238

11 Liu Z, Zhang T, Wang Y, et al. Electronic properties of a new allinorganic perovskite $\mathrm{TlPbI}_{3}$ simulated by the first principles. Nanoscale Res Lett, 2017, 12: 232

12 Waleed A, Tavakoli MM, Gu L, et al. Lead-free perovskite nanowire array photodetectors with drastically improved stability in nanoengineering templates. Nano Lett, 2016, 17: 523-530

13 Yin X, Guo Y, Xue Z, et al. Performance enhancement of perovskite-sensitized mesoscopic solar cells using Nb-doped $\mathrm{TiO}_{2}$ compact layer. Nano Res, 2015, 8: 1997-2003

14 Wang $\mathrm{Y}, \mathrm{Wu}$ J, Zhang $\mathrm{P}$, et al. Stitching triple cation perovskite by a mixed anti-solvent process for high performance perovskite solar cells. Nano Energy, 2017, 39: 616-625

15 Gu X, Wang Y, Zhang T, et al. Enhanced electronic transport in $\mathrm{Fe}^{3+}$-doped $\mathrm{TiO}_{2}$ for high efficiency perovskite solar cells. J Mater Chem C, 2017, 5: 10754-10760

16 Li S, Zhang $\mathrm{P}$, Chen $\mathrm{H}$, et al. Mesoporous $\mathrm{PbI}_{2}$ assisted growth of large perovskite grains for efficient perovskite solar cells based on ZnO nanorods. J Power Sources, 2017, 342: 990-997

17 Zhang $\mathrm{P}, \mathrm{Wu}$ J, Zhang $\mathrm{T}$, et al. Perovskite solar cells with $\mathrm{ZnO}$ electron-transporting materials. Adv Mater, 2018, 30: 1703737

18 Burschka J, Pellet N, Moon SJ, et al. Sequential deposition as a route to high-performance perovskite-sensitized solar cells. Nature, 2013, 499: 316-319

19 Luo J, Jia C, Wan Z, et al. The novel dopant for hole-transporting material opens a new processing route to efficiently reduce hysteresis and improve stability of planar perovskite solar cells. J Power Sources, 2017, 342: 886-895

20 Niu G, Li W, Li J, et al. Progress of interface engineering in perovskite solar cells. Sci China Mater, 2016, 59: 728-742

21 Ko HS, Lee JW, Park NG. 15.76\% efficiency perovskite solar cells prepared under high relative humidity: importance of $\mathrm{PbI}_{2}$ morphology in two-step deposition of $\mathrm{CH}_{3} \mathrm{NH}_{3} \mathrm{PbI}_{3}$. J Mater Chem A, 2015, 3: 8808-8815

22 Zheng E, Wang XF, Song J, et al. $\mathrm{PbI}_{2}$-based dipping-controlled material conversion for compact layer free perovskite solar cells. ACS Appl Mater Interfaces, 2015, 7: 18156-18162

23 Zheng $\mathrm{H}$, Wang $\mathrm{W}$, Yang $\mathrm{S}$, et al. A facile way to prepare nanoporous $\mathrm{PbI}_{2}$ films and their application in fast conversion to $\mathrm{CH}_{3-}$ $\mathrm{NH}_{3} \mathrm{PbI}_{3}$. RSC Adv, 2016, 6: 1611-1617

24 Li M, Yan X, Kang Z, et al. Enhanced efficiency and stability of perovskite solar cells via anti-solvent treatment in two-step deposition method. ACS Appl Mater Interfaces, 2017, 9: 7224-7231

25 Wang $\mathrm{Y}, \mathrm{Li} \mathrm{S}$, Zhang $\mathrm{P}$, et al. Solvent annealing of $\mathrm{PbI}_{2}$ for the high-quality crystallization of perovskite films for solar cells with efficiencies exceeding 18\%. Nanoscale, 2016, 8: 19654-19661

26 Li S, Zhang $\mathrm{P}$, Wang $\mathrm{Y}$, et al. Interface engineering of high efficiency perovskite solar cells based on $\mathrm{ZnO}$ nanorods using atomic layer deposition. Nano Res, 2017, 10: 1092-1103

27 Yi C, Li X, Luo J, et al. Perovskite photovoltaics with outstanding 
performance produced by chemical conversion of bilayer mesostructured lead halide/ $\mathrm{TiO}_{2}$ films. Adv Mater, 2016, 28: 2964-2970

28 Swarnkar A, Marshall AR, Sanehira EM, et al. Quantum dot-induced phase stabilization of $\alpha-\mathrm{CsPI}_{3}$ perovskite for high-efficiency photovoltaics. Science, 2016, 354: 92-95

29 Ma Q, Huang S, Wen X, et al. Hole transport layer free inorganic CsPbIBr 2 perovskite solar cell by dual source thermal evaporation. Adv Energy Mater, 2016, 6: 1502202

30 Xiao Z, Kerner RA, Zhao L, et al. Efficient perovskite light-emitting diodes featuring nanometre-sized crystallites. Nat Photon, 2017, 11: 108-115

31 Yuan M, Quan LN, Comin R, et al. Perovskite energy funnels for efficient light-emitting diodes. Nat Nanotechnol, 2016, 11: 872-877

32 Leyden MR, Meng L, Jiang Y, et al. Methylammonium lead bromide perovskite light-emitting diodes by chemical vapor deposition. J Phys Chem Lett, 2017, 8: 3193-3198

33 Xiao Z, Dong Q, Bi C, et al. Solvent annealing of perovskiteinduced crystal growth for photovoltaic-device efficiency enhancement. Adv Mater, 2014, 26: 6503-6509

34 Ren Y, Duan B, Xu Y, et al. New insight into solvent engineering technology from evolution of intermediates via one-step spincoating approach. Sci China Mater, 2017, 60: 392-398

35 Sun X, Zhang C, Chang J, et al. Mixed-solvent-vapor annealing of perovskite for photovoltaic device efficiency enhancement. Nano Energy, 2016, 28: 417-425

$36 \mathrm{Wu}$ WQ, Chen D, Huang F, et al. Optimizing semiconductor thin films with smooth surfaces and well-interconnected networks for high-performance perovskite solar cells. J Mater Chem A, 2016, 4: 12463-12470

37 Liu D, Wu L, Li C, et al. Controlling $\mathrm{CH}_{3} \mathrm{NH}_{3} \mathrm{PbI}_{3-x} \mathrm{Cl}_{x}$ film morphology with two-step annealing method for efficient hybrid perovskite solar cells. ACS Appl Mater Interfaces, 2015, 7: 1633016337

38 Liu J, Gao C, He X, et al. Improved crystallization of perovskite films by optimized solvent annealing for high efficiency solar cell. ACS Appl Mater Interfaces, 2015, 7: 24008-24015

39 Yu H, Liu X, Xia Y, et al. Room-temperature mixed-solvent-vapor annealing for high performance perovskite solar cells. J Mater Chem A, 2016, 4: 321-326

40 Liu C, Wang K, Yi C, et al. Efficient perovskite hybrid photovoltaics via alcohol-vapor annealing treatment. Adv Funct Mater, 2016, 26: 101-110

41 Ding X, Ren Y, Wu Y, et al. Sequential deposition method fabricating carbonbased fully-inorganic perovskite solar cells. Sci China Mater, 2018, 61: 73-79

42 Wang WT, Das SK, Tai Y. Fully ambient-processed perovskite film for perovskite solar cells: effect of solvent polarity on lead iodide. ACS Appl Mater Interfaces, 2017, 9: 10743-10751

43 Zhang T, Yang M, Zhao Y, et al. Controllable sequential deposition of planar $\mathrm{CH}_{3} \mathrm{NH}_{3} \mathrm{PbI}_{3}$ perovskite films via adjustable volume expansion. Nano Lett, 2015, 15: 3959-3963

44 Kim YC, Jeon NJ, Noh JH, et al. Beneficial effects of $\mathrm{PbI}_{2}$ incorporated in organo-lead halide perovskite solar cells. Adv Energy
Mater, 2016, 6: 1502104

45 Jacobsson TJ, Correa-Baena JP, Halvani Anaraki E, et al. Unreacted $\mathrm{PbI}_{2}$ as a double-edged sword for enhancing the performance of perovskite solar cells. J Am Chem Soc, 2016, 138: 1033110343

46 Kamrin K. Cracks by design. Nat Mater, 2017, 16: 8-9

$47 \mathrm{Hu} \mathrm{W}, \mathrm{Wu} \mathrm{R}$, Yang S, et al. Solvent-induced crystallization for hybrid perovskite thin-film photodetector with high-performance and low working voltage. J Phys D-Appl Phys, 2017, 50: 375101

48 Rao HS, Li WG, Chen BX, et al. In situ growth of $120 \mathrm{~cm}^{2} \mathrm{CH}_{3}$ $\mathrm{NH}_{3} \mathrm{PbBr}_{3}$ perovskite crystal film on FTO glass for narrowbandphotodetectors. Adv Mater, 2017, 29: 1602639

49 Hu W, Huang W, Yang S, et al. High-performance flexible photodetectors based on high-quality perovskite thin films by a vaporsolution method. Adv Mater, 2017, 29: 1703256

50 Dong J, Xu X, Shi JJ, et al. Suppressing charge recombination in $\mathrm{ZnO}$-nanorod-based perovskite solar cells with atomic-layer-deposition $\mathrm{TiO}_{2}$. Chin Phys Lett, 2015, 32: 078401

51 Gonzalez-Pedro V, Juarez-Perez EJ, Arsyad WS, et al. General working principles of $\mathrm{CH}_{3} \mathrm{NH}_{3} \mathrm{PbX}_{3}$ perovskite solar cells. Nano Lett, 2014, 14: 888-893

52 Lee DS, Kim W, Cha BG, et al. Self-position of Au NPs in perovskite solar cells: optical and electrical contribution. ACS Appl Mater Interfaces, 2016, 8: 449-454

53 Luo $\mathrm{P}$, Xia W, Zhou S, et al. Solvent engineering for ambient-airprocessed, phase-stable $\mathrm{CsPI}_{3}$ in perovskite solar cells. J Phys Chem Lett, 2016, 7: 3603-3608

54 Fu Y, Rea MT, Chen J, et al. Selective stabilization and photophysical properties of metastable perovskite polymorphs of $\mathrm{CsPbI}_{3}$ in thin films. Chem Mater, 2017, 29: 8385-8394

55 Bi E, Chen H, Xie F, et al. Diffusion engineering of ions and charge carriers for stable efficient perovskite solar cells. Nat Commun, 2017, 8: 15330

56 Arora N, Dar MI, Hinderhofer A, et al. Perovskite solar cells with CuSCN hole extraction layers yield stabilized efficiencies greater than $20 \%$. Science, 2017, 358: 768-771

Acknowledgements This work was supported by the National Natural Science Foundation of China $(61574029,61421002$ and 61574029). This work was also partially supported by University of Kentucky.

Author contributions Wang Y, Chen Z and Li S designed the experiment. Wang $\mathrm{Y}$ and $\mathrm{Li} J$ performed the main experiment and analyzed the results. Liu D and Zhang P performed XRD measurement. Zhang $\mathrm{T}$ and Waseem performed UV-Vis absorption characterization. Ying X performed the EIS measurement. Wang F carried out samples stability test. $\mathrm{Wu} \mathrm{J}$ and Chen $\mathrm{L}$ modified the manuscript. All authors participated in the discussion of the research.

Conflict of interest The authors declare no conflict of interest.

Supplementary information Supplementary information is available in the online edition of the paper. 


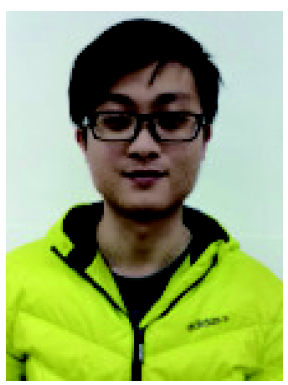

Yafei Wang received his bachelor's degree in electronic science and technology from Huaqiao University in 2012. He is currently a PhD candidate of optical engineering at the University of Electronic Science and Technology. His study mainly focuses on the synthesis and application of functional nanomaterials for perovskite solar cells.
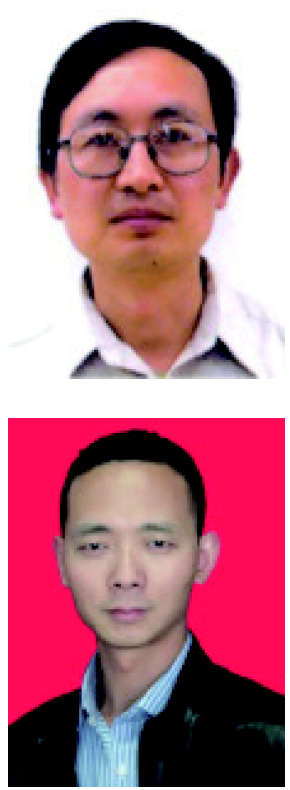

Zhi David Chen received his PhD degree in electrical engineering from the University of Illinois at Urbana-Champaign in 1999. He was Assistant Professor in 1999 and Associate Professor in 2004, and is currently Professor of Electrical Engineering at University of Kentucky. He is also Visiting Professor at the University of Electronic Science and Technology of China. He was Associate Director of Center for Nanoscale Science and Engineering and Director of Graduate Studies of the Electrical \& Computer Engineering at University of Kentucky. He has published over 80 papers in refereed journals and over 50 in conference proceedings.
Shibin Li is currently a Professor in the School of Optoelectronic Science and Engineering at the University of Electronic Science and Technology of China (UESTC). He received his PhD from UESTC in 2008. He joined the Department of Electrical \& Computer Engineering at the University of Kentucky and University of Arkansas, USA, as a postdoctoral fellow in 2008.9 and 2009.9, respectively. He was an Associate Professor in UESTC from 2011 before his current position. His research group focuses on nanoscale materials for solar cells, flexible sensors and photodetectors.

\section{通过弱配位溶剂退火揭示钙铁矿薄膜生长机制}

王亚飞 ${ }^{1}$, 刘德涛 ${ }^{1}$ 张鹏 ${ }^{1}$, 张婷 ${ }^{1}, W a s e e m \mathrm{Ahmad}^{1}$, 应翔霄 ${ }^{1}$, 王峰 ${ }^{1}$, 李健 ${ }^{1}$, 陈力 ${ }^{1}$, 巫江 ${ }^{3,4}$, 陈志 ${ }^{1,2^{*}}$, 李世樹 ${ }^{*}$

摘要 本研究在两步法沉积 $\mathrm{CH}_{3} \mathrm{NH}_{3} \mathrm{PbI}_{3}$ 和一步法沉积 $\mathrm{CsPbI}_{3}$ 薄膜过程中使用弱配位溶剂异丙醇( IPA)对钲钛矿及钲钛矿前驱体进行溶剂 退火处理, 从而揭示了钲钛矿薄膜的成核机理. 同时研究了退火温度对两步法中 $\mathrm{PbI}_{2}$ 前驱体进行溶剂退火处理时的作用. 发现IPA溶剂退 火工艺严重影响了 $\mathrm{PbI}_{2}$ 和 $\mathrm{CH}_{3} \mathrm{NH}_{3} \mathrm{PbI}_{3}$ 薄膜的晶粒尺寸、致密度、粗䊅度和薄膜形貌. 相同的弱配位溶剂退火工艺也被应用于制备全无机 $\mathrm{CsPb}_{3}$ 钙钛矿. 通过溶剂退火可以得到具有均匀晶粒尺寸、连续致密的全无机 $\mathrm{CsPb}_{3}$ 薄膜. 我们认为弱配位溶剂退火工艺可以通过有效地 调控钙钛矿中间相中的残留溶剂量来影响钙钛矿成膜中的再结晶过程. 通过IPA溶剂退火工艺, $\mathrm{CH}_{3} \mathrm{NH}_{3} \mathrm{PbI}_{3}$ 钙钛矿太阳能电池光电转换 效率达到 $17.4 \%$, 而 $\mathrm{CsPbI}_{3}$ 的光电转换效率达到了 $2.5 \%$. 